\title{
Does Familiarity Breed Contempt? Inter-Ethnic Contact and Support for Illiberal Parties ${ }^{1}$
}

\author{
Jeffrey S. Kopstein \\ University of Toronto \\ jeffrey.kopstein@utoronto.ca
}

\author{
Jason Wittenberg \\ University of California, Berkeley \\ witty@berkeley.edu
}

September 8, 2006

${ }^{1}$ A preliminary version of this paper was presented at the 2005 meetings of the American Political Science Association. We also thank seminar participants at UC Berkeley, UCLA, and LiCEP for helpful comments. For research support we thank the National Council for Eurasian and East Europe Research and the National Science Foundation (SES-0217499). 


\begin{abstract}
Does contact between ethnic groups lead to greater support for liberal parties? Research on this debate in the US context is contaminated by high levels of mobility and a truncated party palette. This paper addresses the problem through a detailed examination of the 1929 and 1935 national parliamentary elections in Czechoslovakia, where mobility was relatively limited, the spectrum of parties was broad, and the ethnic groups were numerous. We employ ecological inference techniques on an original database of election and census results to estimate Czech, Slovak, Hungarian, and German support for liberal, fascist, nationalist, populist, and communist parties across a variety of local ethnic demographic configurations. The results show that on its own, inter-ethnic contact has indeterminate electoral effects: no uniform pattern of support for liberal parties exists either across or within ethnic groups. Contrary to expectation, this finding holds under both ethnically cooperative and conflictual national political environments. We surmise that this electoral behavior may be rooted as much in national demography and party organization as in the constraints posed by the local demographic context.
\end{abstract}




\section{Introduction}

Comparativists tend to be pessimistic about the impact of ethnic diversity on democracy. Multiethnic democracies are seen as especially vulnerable to the kind of polarizing and zero-sum political competition that can breed communal conflict, simmering resentments, ethnic outbidding, and increased support for parties espousing ethnic hatred and anti-liberal politics (Dahl 1971; Horowitz 1985; Lijphart 1977). The purpose of this paper is to investigate the relationship between ethnic demography and mass electoral preferences for ethnically intolerant and anti-system political parties. We are interested in how popular support varies across different local demographic contexts. Does familiarity breed contempt? Or does real-life interaction mitigate animosity?

Despite decades of research, scholars still disagree on why contact between groups leads in some cases toward greater tolerance and cooperative behavior across groups, while in other cases toward increased prejudice and political polarization. Good theoretical arguments have been made for both perspectives. In favor of the salutary effects of ethnic proximity, proponents of the contact hypothesis argue that prejudice and intolerance are rooted in individual ignorance of other groups, which can be ameliorated through contact between groups (e.g., Brewer and Miller 1988; Siegelman and Welch 1993; Siegelman, Welch, and Bledsoe 1996; Welch and Siegelman 2000). In this view, the greater the level of contact between groups, the more each group learns about the other, and the greater the realization of shared interests and values. As stereotypes erode, understanding and tolerance should increase across groups. At the political level this implies that, all other things being equal, ethnic groups in close contact ought to prefer inclusionary and liberal over other parties.

Proponents of the threat hypothesis take the opposite tack (e.g., Blumer 1958; Blalock 1967; Bobo and Hutchings 1996). While not denying the theoretical advantages of contact, they emphasize how the demographic balance influences the degree to which one group perceives other groups as threats. Threat perception may be rooted in actual competition over resources and jobs, or in hazier fears of social and political vulnerability to people who are seen to have different values and ways of life. Either way, the propinquity of ethnic groups is thought to induce suspicion and hostility rather than mutual tolerance. Translated to the political level, this view implies that parties seeking to capitalize on inter-group hostility should find their greatest success in ethnically heterogeneous areas.

The tension between the two approaches lies as much in research design and method as it does in theory. Much of the work has focused on race relations and politics in the U.S., where the wide availability of detailed survey and ecological data has facilitated sophisticated attempts to bridge the theoretical divide (e.g., Oliver and Wong 2003; Stein, Post, and Rinden 2000). As troubled as race relations have been in the U.S., however, there are two features of the American context that complicate efforts to test the two competing hypotheses. First, extreme levels of residential and professional mobility mean that it is difficult to determine the direction of causality. For example, the correlation between intergroup contact and tolerance may be less a result of learning than the prior decision of tolerant people to live in ethnically mixed areas. In the latter case, it is tolerance that leads to inter- 
ethnic contact, rather than vice versa. To avoid this conundrum, some scholars have shifted from observational to experimental research, where the variables at work can be manipulated in a semi-controlled setting (Glazer 2003). Of course, what is gained in methodological rigor is lost in empirical validity: however realistic the experiment, it is not at all clear that the conclusions travel very well back to the real world.

The second troublesome feature of the U.S. context concerns its truncated party political palette. The dominance of two liberal democratic parties and the institutional barriers to the success of alternatives means that the U.S. party spectrum does not reflect whatever potential mass constituencies exist for exclusionary or anti-liberal politics. Instances of political extremism such as George Wallace's presidential candidacy and David Duke's various attempts to capture state office in Louisiana do provide important opportunities to test the threat hypothesis (Wright 1977; Giles and Bruckner 1993; Voss 1996), but these are the exceptions that prove the rule. We simply do not know who would support hypothetical African-American, Hispanic, communist, or fascist parties if the rules of the game were changed in a way that increased their potential viability.

\section{Research Design}

In this paper we test the contact and threat hypotheses through a detailed examination of electoral behavior in interwar Czechoslovakia. The principal advantage of taking the hypotheses so far afield is that Czechoslovakia provides some remedy for the two aforementioned deficiencies of the U.S. case. First, although the country was undergoing urbanization at the time, the level of mobility in Czechoslovakia was far below that of the post-World War II U.S. The great wave of out-migration to other countries had ceased after World War I, and although the cities continued to attract rural folk, neither the labor nor the housing markets were flexible enough to give many the luxury of choosing where they could live. Most people were stuck where they were. The analysis will therefore be less contaminated by the selection effect.

Second, interwar Czechoslovakia's electoral system featured a combination of proportional representation and relatively low thresholds to enter parliament. Consequently, it enjoyed a remarkably diverse array of viable political parties. The interwar period may be best known for authoritarianism, but it was a golden age for political diversity. Fascism and communism had not yet been discredited, and they competed alongside nationalist and liberal democratic parties for mass support. We discuss various political parties in the following section.

Interwar Czechoslovakia has two other features that make it an excellent venue for this research. First, there is good reason to expect Czechoslovakia's ethnic demography to be a powerful determinant of political behavior. The lands comprising Czechoslovakia had been multiethnic for centuries, and numerous stereotypes and mutual prejudices had arisen under Hapsburg rule. The arrogant, exploitative German and backward, clerical Slovak had become a staple of Czech literature. In the Slovak popular imagination the Czechs were hypocritical urban sophisticates, the Hungarians nationalist usurpers. Hungarian discourse, for it's part, held Slovaks 
in disdain and suitable for forced assimilation (Wiskemann 1938; King 2002; Seton Watson 1908). The founding of the new states after World War I gave new life to these prejudices by reshuffling the ethnic hierarchy. Czechs who were inferior to the Germans in the ethnic pecking order in the Hapsburg era but superior in the ethnic pecking order to Slovaks, now ruled in tandem with the Slovaks over Germans and Hungarians (and Jews). This reversal of ethnic fortunes rendered interwar ethnic relations particularly volatile. Although class and rural/urban cleavages were pronounced in Czechoslovakia and throughout East-Central Europe in the interwar period, most historians maintain that the deepest and most important divides in these societies were ethnic (e.g., Rothschild 1974, Polonsky 1972).

Second, Czechoslovakia held regularly-scheduled free and fair national parliamentary elections. We examine two, in 1929 and 1935. The advantage of these is that they took place under very different political circumstances. Whereas the 1929 election occurred before the global economic crisis and subsequent international political turbulence, the 1935 election took place well after the Nazi seizure of power in Germany, the turn to Stalinism in the Soviet Union, and the general authoritarian turn in Europe as a whole. The dissolution of democracy in neighboring countries, and in Germany in particular, emboldened the Czech, German, and Slovak fascists to shed some of their prior fealty to the republic. Konrad Henlein's Sudeten German Nazi party now considered itself the sole legitimate representative of the Germans, and attempted to corral the other German parties under its aegis, while some in Hlinka's Slovak People's Party began to speak of an independent clerical state rather than merely autonomy within Czechoslovakia. As Hlinka's party became more strident, so too did the political representatives of Slovakia's Hungarians, who received substantial support from the authoritarian and revisionist regime in Budapest. Fascism and minority nationalism were further energized by the perceived danger of socialism. The Czechoslovak Communist Party, which appealed to ethnic minorities in addition to the working class, was openly pro-Moscow. This was clearly a time of increased ethno-political polarization. By analyzing both the 1929 and 1935 elections we are able to see how changing national-level ethnic tensions are refracted through local demographic configurations. We expect that such tensions will translate into increased support for the threat hypothesis.

The paper proceeds as follows. Section 3 elaborates in more detail the electoral and demographic context of interwar Czechoslovakia. Section 4 outlines the ecological inference methods on which our analysis is based. Our main results come in section 5, where we explore the ethnic bases of party support in the 1929 and 1935 national parliamentary elections. In section 6 we perform robustness checks by re-estimating a few key results while controlling for levels of industrialization. The conclusion follows in section 7 .

To anticipate our results, we find that neither the contact nor the threat hypothesis holds general sway within Czechoslovakia. Local ethnic demography does not exercise a consistent or sustained impact either across groups or for a given group over time. Generally speaking, the threat hypothesis holds for the ruling Czechs and formerly ruling Hungarians: they were at their most politically moderate when living in relative local isolation from other national groups. For the Slovaks, nominally co-rulers but in fact subordinate to the Czechs, contact appears to moderate polit- 
ical behavior. They proved most vulnerable to extremist appeals when they were concentrated in their own localities. Although we offer plausible explanations for different behavioral responses to local ethnic demography, each requires departing from any single logic of contact or threat.

\section{Parties and Ethnic Groups}

\subsection{Parties}

Interwar Czechoslovakia was, by the standards of the day, a solid democracy. Four national elections occurred, in 1920, 1925, 1929, and 1935. Most students of the era consider them to be free and fair, even if in the Eastern part of the country there was a modest amount of administrative pressure applied to the minority population. ${ }^{1}$ Czechoslovakia's electoral rules provided fertile ground for creating a large number of class, ethnic, and regionally based political parties, in all more than 50 during the interwar era. Understanding the impact of ethnic balance on voting for intolerant and polarizing parties in Czechoslovakia requires a short precis of the main parties and blocs of parties of interest in this paper. The full breakdown of parties and party blocs can be seen in an Appendix. The main cleavage in interwar Czechoslovak politics divided those parties welcoming the creation of a democratic Czechoslovak republic and those who did not. Because of the highly proportional voting rules, stable government required the cooperation of the pro-republican parties, something achieved by the leadership of the five largest Czech republican parties running from bourgeois-conservative to social democratic in the quasi-corporatist institution of the Petka. ${ }^{2}$ The pro-republican parties differed on important questions of domestic and foreign policy. What they shared was a commitment to the existence of building a Czechoslovak nation within a liberal democratic Czechoslovak state.

From the outset, the most serious challenge to Czechoslovakia's liberal landscape came from ethnically and non-ethnically based extremist parties. The ethnically based extremist parties opposed the liberal universalism of Czechoslovak state and the institutions of liberal democracy. Such hostility did not prevent these parties from campaigning for office in elections. They did so, and sometimes with great skill, from both the right and left side of the political spectrum. Among ethnic Germans the extremist and irredentist German National Party (DNP) and the German National Socialist Workers Party (DNSAP), a proto-Nazi organization, rejected liberal democracy, preached anti-semitism, and vilified the Czechoslovak state. After 1932 both parties were superceded by the pro-Nazi Sudeten German Party whose leader, Konrad Henlein, emerged from relative obscurity as a gymnastics instructor to capture 15 percent of the national vote in 1935, the largest share of any party in Czechoslovakia.

In contrast to the German extreme right, the ethnic right among Slovaks was primarily clerical in orientation. It revolved around the figure of Andrej Hlinka, a

\footnotetext{
${ }^{1}$ This area, Subcarpathian Rus, is excluded from the analysis.

${ }^{2}$ The parties in the Pĕtka were the Agrarian, the Social Democrats, the National Socialists (a moderate left party based in Bohema and Moravia), the Czechoslovak Populists (a clerical party catering to Catholics), and the National Democrats (a bourgeois conservative party).
} 
Catholic Priest, and his Slovak People's Party (SPP). The SPP espoused a populist, anti-modernist, and anti-semitic message. Whereas Germans rejected Prague because it represented the rule of culturally 'inferior' Czechs, the SPP traded on resentment among Slovaks against Czech domination supposedly masked by the official ideology of Czechoslovakism (Felak 1994). The main bone of contention for the Slovak right was Slovakia's share of power within the country. Whereas many Slovaks believed that a common state with the Czechs would be federal in character, the final product more closely resembled French centralism, a model that threatened the place of the Catholic Church in Slovak society and its traditional role in education and public life. Czechs dominated the civil service at the national level and, along with Slovak Protestants, occupied a disproportionate share of high profile positions within Slovakia itself (Leff 1988, Janos 1997). The SPP consistently received the highest proportion of any party in the Slovak lands, garnering 28 percent of the Slovak portion of the national vote in 1929 and 30 percent in 1935.

On the extreme Left was the Communist Party of Czechoslovakia (CPCz). In contrast to the ethnic right, the extreme left in interwar Europe espoused a universalist message, one of class solidarity A vote for the communists was not a vote against another ethnic group, but against liberal democracy in favor of a new kind of anti-capitalist cosmopolitanism. Like other European Communist parties, the $\mathrm{CPCz}$ emerged from a split with the Social Democrats after the Russian Revolution and the founding of the communist international. By 1929 the $\mathrm{CPCz}$ purged its remaining independent elements and fully bolshevized the party. The electoral platform of the CPCZ was straightforward. It called for a worker's revolution and a dictatorship of the proletariat. Social Democrats were characterized by the $\mathrm{CPCz}$ in the 1929 campaign as "social fascists" and the leader of the party, Klement Gottwald, declared openly in parliament his party's "highest revolutionary headquarters is actually Moscow." (Oschlies in Bosl 1979, p.181) Although they did not run on an ethnic platform, the Czechoslovak communists enthusiastically exploited ethnic grievances for their political ends. In fact, the $\mathrm{CPCz}$ campaigned throughout the country and was especially active where it expected to benefit from dissatisfaction with pro-Republican parties among ethnic minorities.

\subsection{Ethnic Groups}

As Brubaker (1993) notes, the dominant nationality of each nation-state claimed "ownership" of the state, a clear source of tension in what were deeply multicultural societies. These efforts were reflected in the very way these states counted their own people, the census. Czechoslovakia conducted two censuses, in 1921 and 1930. Since it was carried out between the time of the two elections to be analyzed, we use the 1930 census materials. The most obvious peculiarity of this census was the amalgamation of Czechs and Slovaks into one category ("Czechoslovaks") for purposes of enumeration. Apart from the desire to assert the unity of the new Czechoslovak nation, the primary motivation behind this typological peculiarity was all too obvious to observers at the time: if Czechs and Slovaks were counted separately, Germans would outnumber Slovaks. This quirk of the data does not affect the analysis because almost all Czechs lived in Bohemia and Moravia, while 
Slovaks lived in Slovakia. Germans lived throughout the country but were highly concentrated (constituting overwhelming majorities) in the Sudetenland, comprising approximately 23 percent of the total population of the country. Approximately 700,000 Hungarians lived in Slovakia as a large and deeply dissatisfied minority. Observers of the day disputed elements of the census which, they maintained, systemically undercounted ethnic Hungarians, but these miscounts were not large and the census is considered by historians to be professional and accurate.

\section{Estimation Methods}

Our data are ecological: 1930 census data, and the actual results from the 1929 and 1935 national parliamentary elections. We collected these data at the lowest level at which they could be matched, the municipality. In the case of Prague, we use municipal districts, but most of the observations are village (obec)-level. The result is a data set of over 15,000 matched settlements for which we have the ethnic makeup as well as the voting results. ${ }^{3}$ Other social and economic data are available only at one administrative level above the municipality, the okres (district) level. We discuss the okres-level data further below.

We use recently-developed ecological inference techniques to estimate group preferences for political parties. ${ }^{4}$ The best of these methods combines deterministic information about the possible values of the quantity of interest (in this case the fraction of a particular social group in a locality that could hypothetically have supported a given party or bloc) with a statistical model of what the most likely values of that quantity are within that range of possibilities. Although highly popular, the method in King (1997) is not easily applicable in ethnically and politically heterogeneous situations where there are more than two national groups and parties. Instead, we employ the nonlinear least squares approximation of the multinomial-Dirichlet model presented in Rosen et al. (2001), which yields consistent estimates for arbitrarily large tables. For details of this model we refer the reader to the original article. $^{5}$

In the absence of surveys or other systematic data on the actual degree and nature of contact between national groups, we use proximity as a proxy. We recognize the risks inherent in this strategy. Much like in the US, where different ethnic groups might dwell in adjoining areas of town but rarely ever see one another, it is possible that East European national groups lived "in separate worlds." We

\footnotetext{
${ }^{3}$ These data are being collected under the auspices of our larger project, "Majorities and Minorities: A New Look at Ethnonationalism and Electoral Extremism," with generous funding from NCEEER and NSF (SES-0217499).

${ }^{4}$ No survey data are available for this period, but even if it were, there are good reasons why it might be unreliable for our purposes. It is well known in survey research that respondents are often reticent about expressing unpopular sentiments to their interviewers. Consequently, surveys of political preferences will tend to underestimate the actual level of support for extremist parties. This effect may be heightened by ethnic differences between the interviewer and the respondent. Of course it would be best to have both kinds of data to test for consistency between the two, but historical research places limits on method.

${ }^{5}$ All estimates are performed in $\mathrm{R} 2.2 .0$ with the code described in Wittenberg and Bhaskar (2005).
} 
offer two pieces of evidence in defense of our assumption. First, the bulk of our observations are villages with small populations. The median population of our Czechoslovak settlements is only 434. It is not so easy to lead a separate existence when there is at most one market, one post office, and one school. Second, and more importantly, the historical literature reveals multi-layered relations among national groups. Consider, for example, Germans in Czechoslovakia. In some portions of Czechoslovakia, Germans lived largely on their own and actually needed to have little contact with Czechs. However, in the cities of Bohemia not only was there extensive and intensive contact between Czechs and Germans, but historians have documented quite carefully that the same people frequently moved back and forth between these communal identities. The contact between the two groups was so intensive in many places that by 1930, many Germans were in the process of becoming Czechs, a process that naturally raised alarms among leaders of the German community (King 2002, pp.165-168; Wiskemann, 1967, pp.231-234). Much the same can be said for the Hungarian minority.

\section{Results}

\section{$5.1 \quad 1929$}

We begin our analysis with the 1929 national parliamentary elections. Our estimates of the social bases of the main party blocs appear in Figure 1. Since Czechoslovakia was constructed out of territories that had been a part of other empires, each of which had a different configuration of national groups, we present a separate panel for each region. In each panel, the horizontal axis represents the fraction of the titular majority, Czechs and Slovaks, ranging from zero (settlements without any Czechs or Slovaks) to one (purely Czech or Slovak settlements). The numerical strength of minority groups in a settlement is inversely related to the strength of the majority groups. Thus, the upper horizontal axis indicates the fraction of minority groups, with zero on the right and one on the left. ${ }^{6}$ The vertical axes represent the fraction of a particular national group that supported a given bloc/party, again ranging from zero (no one in group $\mathrm{x}$ supported bloc y) to one (everyone in group $\mathrm{x}$ supported bloc y).

Each point (denoted by a capital letter) represents an individual estimate. The interpolated lines connecting the same letter indicate how a group's support for a bloc changes with the demographic strength of Czechs and Slovaks across settlements. Different line types used to connect letters (solid, dashed) represent different national groups. Thus, in the Bohemia and Moravia panels, solid lines represent Czech voting behavior, whereas the dashed lines represent German. The letters used on the lines stand for the names of blocs. Thus, for Figure 1, we have (G)erman parties (ethnic but full participants in the Republic), (R)epublican parties, the (C)ommunist Party, the extreme right-wing German (N)ationalist parties, (E)thnic parties for Hungarians, Poles, and Jews, and Hlinka's (P)opulist Slovak

\footnotetext{
${ }^{6}$ There were small Jewish and other minorities in Bohemia, Moravia, and Slovakia, but their numbers are too insignificant, or were distributed across too few settlements (in the Jewish case) to include in the analysis.
} 
Bohemia, 1929

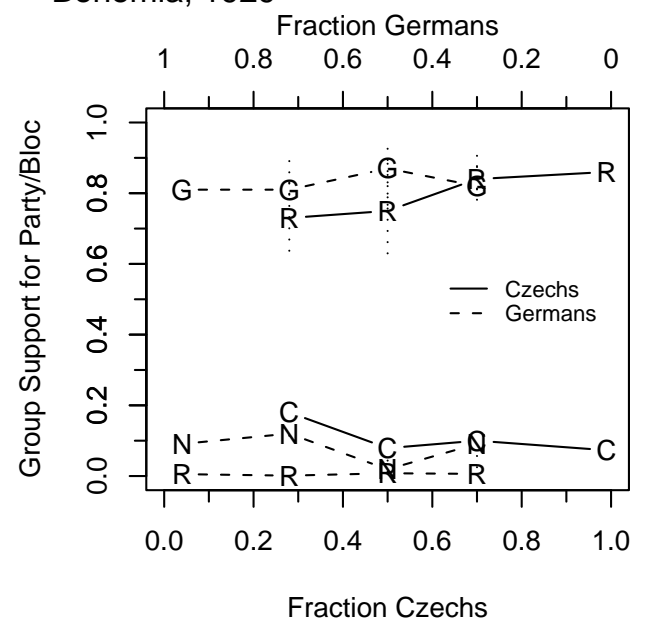

Slovakia, 1929

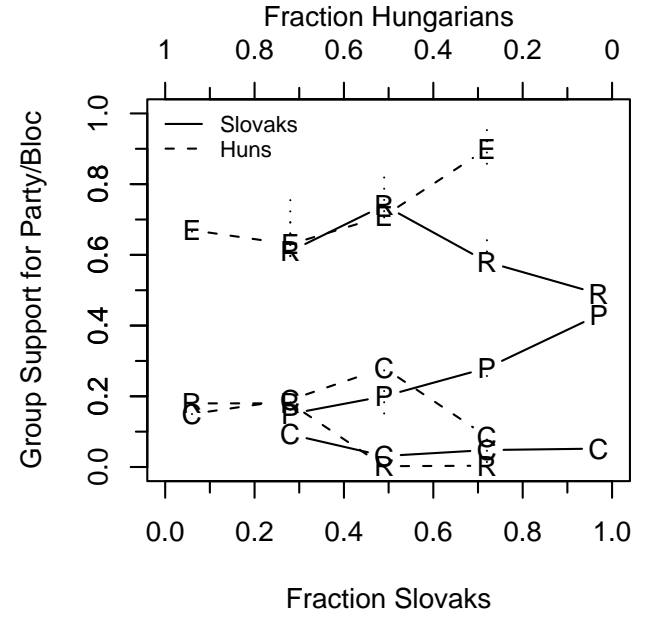

Moravia, 1929

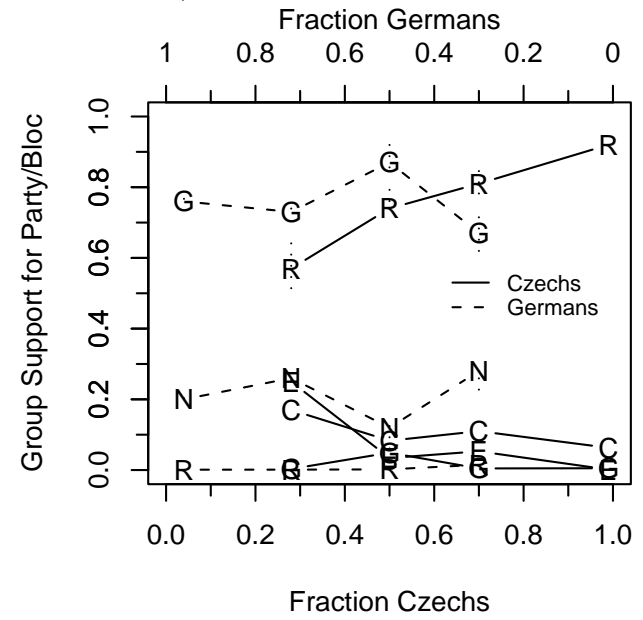

Key for Parties

R=Republican (Czechoslovak)

$\mathrm{C}=$ Communist

$\mathrm{N}=\mathrm{G}$. Natlist/Nazi

$\mathrm{G}=$ German

$\mathrm{P}=$ Populists (Hlinka)

$\mathrm{E}=$ Ethnic min. non-German

Figure 1: Czechoslovakia 1929: Social Bases of Party Support

People's Party. ${ }^{7}$ For example, in Bohemia we estimate that roughly 70 percent of Czechs who resided in settlements that were 20 percent to 40 percent Czech voted for (R)epublican parties (the leftmost R), whereas over 80 percent of Germans that lived in Czech-dominated (60 percent to 80 percent) areas supported ( $\mathrm{G}$ )erman parties (the rightmost $\mathrm{G}$ ). A similar logic holds for the other panels, and will hold for other figures, though the identities of the parties and the national groups may vary. We also display 95 percent confidence intervals, as vertical lines, around estimates for those parties receiving a significant portion of a group's vote. ${ }^{8}$

Interpreting these plots takes some getting used to, but it's worth the effort, because they make it quite easy to see whether or not there is an effect to be

\footnotetext{
${ }^{7}$ (R)epublican parties include all liberal democratic "Czechoslovak" parties, not just the Czechoslovak Republican Party.

${ }^{8}$ We report bootstrapped percentile confidence intervals based on 500 bootstrap replications. Due to limited variance and hence uncertain results, in most cases we do not generate estimates of a group's voting behavior when that group is less than 20 percent of a settlement's population.
} 
explained: the flatter the line, the less contact matters. In Figure 1 this is most visible in German voting behavior in Bohemia and Moravia (dashed lines). Support for $(\mathrm{G})$ erman parties was between 80 and 90 percent in both German-dominated settlements (the leftmost $\mathrm{G}$ ) as well as Czech dominated-settlements. Support for the German (N)ationalists and the (R)epublican (Czechoslovak) parties remained mired at under 10 percent. Part of the stability of the German vote is rooted in the rich palette of German parties, which allowed for much vote switching within the bloc. Indeed, two of the main German parties, the Social Democrats and the Agrarians, had served in government, and had resisted amalgamating with their Czechoslovak ideological counterparts primarily because this would have ceded the national question to the rejectionist parties (Wingfield, 1989 pp.48-75). A nontrivial proportion of $(\mathrm{G})$ ermans supported extreme German (N)ationalist parties, especially in Moravia.

Although the Germans remained largely immune to the proximity of their national rivals, the same cannot be said for the Czechs, where the upward sloping lines indicating support for (R)epublican parties in Moravia (and to a lesser extent Bohemia) shows that Czech preference for such parties decreased with the increased presence of Germans. Although overall Czech support of these parties remains quite high (70 percent or above), there is nonetheless moderate evidence for the threat hypothesis: as Czechs move from (local) majority to minority, they gravitate toward the $(\mathrm{C})$ ommunists in Bohemia and $(\mathrm{G})$ erman parties in Moravia.

Things get more complicated in the Slovak half of the republic. ${ }^{9}$ On the one hand, Figure 1 shows clear evidence of support for the contact hypothesis among Slovaks. They were much more likely to vote for Hlinka's (P)opulist Slovak People's Party when they were in the local majority. As their proportion of a given settlement falls, they become more likely to vote for (R)epublican parties. One explanation for this behavior is that as a local minority living among Hungarians, Slovaks could appreciate the liberal freedoms of the Czechoslovak republic, including the modicum of autonomy they enjoyed. When on their own, however, they were more easily motivated by dreams of genuine independence rather than mere "autonomy."

Before adopting this interpretation, however, it is important to consider whether it was religion or ethnicity that drove the Hlinka vote. Hlinka's SPP was led by a diverse group of conservative Catholic clerics, many of whom were deeply antisemitic and opposed to social modernization, which they feared would significantly reduce the role of the Church in education, family, and cultural life. The party's clear

\footnotetext{
${ }^{9}$ Most importantly, we must contend with more ethnic groups. Whereas in Bohemia and Moravia the Germans were the preeminent minority, in Slovakia the Slovaks faced non-trivial Jewish, Ruthenian, and German populations alongside the far more numerous Hungarians. This poses a dilemma. On the one hand, the ethnic groups are not distributed across settlements in a way that permits a clean estimation of each group's behavior in the presence of each of the others. In particular, there are too few mixed areas. On the other hand, the nature of any perceived threat may depend on the configuration of ethnic groups. Slovaks, for example, ought to feel a greater threat from Germans and Hungarians than from the demographically and politically weaker Ruthenians and Jews. The reference group for Hungarians, by contrast, might be the ruling Slovaks rather than other minority groups. Our estimates of Slovak and Hungarian voting behavior are based on a sample in which both Jews and Germans constitute less than 10 percent of the population.
} 
Catholic appeal reinforced the salience of a confessional cleavage among Slovaks, a significant minority of whom were Protestant. Hlinka attempted to bridge this divide by emphasizing Slovak oppression by the Hungarians, and later by the Czechs. At the outset of the Republic, Slovaks had been led to believe that the state would contain significant elements of federalism, when in fact its structure much more approximated the French unitary model. The SPP pitched its message directly at this source of resentment among Slovaks, and preached "autonomy" even at the "price of the republic." (Felak 1994, p.54) The campaign message was really that of a "catch-all protest party" with programatic statements, sometimes mutually exclusive ones, aimed at a diverse range of social groups. Historians stress a broad socioeconomic base for the SPP, from poorly educated small town traders, small holding farmers, to the underemployed or unemployable urban intelligentsia (Hoensch 1979, pp.317-318).

In fact, the confessional cleavage among Slovaks was electorally stark. To show this we estimate Roman Catholic and Protestant support for parties in ethnically homogeneous (greater than 99 percent) Slovak settlements. Whereas 65 percent $( \pm .1 \%)$ of Catholics supported Hlinka and only 30 percent $( \pm .1 \%)$ (R)epublican parties, over 94 percent $( \pm .1 \%)$ of Protestants went (R)epublican. Protestants clearly preferred their status as favored interlocutors with their Czech co-rulers in a federal state to an uncertain status under a clerical, Catholic-dominated, more fully autonomous Slovak regime (Mamatey and Luza 1973:78; Rothschild 1974: 120). Unfortunately it is not possible to obtain separate estimates for Catholic and Protestant Slovaks in non-homogeneous settlements. We can infer that levels of Slovak support for (R)epublican and Hlinka's (P)opulists in evenly split and majority Slovak areas represent an average of disparate Catholic and Protestant preferences. What the confessional results tell us is that at least as far as support for Hlinka is concerned, the key identity for political behavior is not ethnic, but religious.

That confession matters more than national identity in determining Slovak preferences for Hlinka's Slovak (P)opulists is surprising at one level. Hungarians were former imperial rulers over all Slovaks, Catholic and Protestant, and were by far the largest minority in the Slovak lands. Many if not most would have preferred to have Slovakia reincorporated back into Hungary. Whereas the German parties were divided between "activists" (those willing to cooperate and serve in government) and "negativists" (those rejecting the Republic outright), none of the Hungarian parties fully accepted the Czechoslovak state (Lipscher 1981:364-372). All Slovaks ought to have been threatened. At another level, however, it makes perfect sense, for unlike the Slovak Protestants, the Slovak (P)opulists rejected the Czechoslovak state, rendering the Hungarians as implicit allies (against Protestants) in the quest to detach Slovakia from the Czech half of the republic. Although Hlinka refused cooperation with Hungarian parties, even when such cooperation would have increased the SPP's success at the ballot box (Felak, 1996, p.79), others in the party were not above using Hungarian irredentist claims to further the autonomist cause.

For Hungarians the threat hypothesis holds in 1929, for the most part. Consider first the (E)thnic parties in Figure 1. Although Hungarians voted heavily for them independently of the ethnic composition of their settlements, support for them is at its height when they live among Slovaks, and falls steadily as they move to local 
majority status. At the same time, their support for (R)epublican parties rises to roughly 20 percent. If (E)thnic parties were one path of Hungarian reaction to the Slovak threat, the $(\mathrm{C})$ ommunist party provided another. Even though the $\mathrm{CPCz}$ did not support the creation of a new ethnic state and resisted the rightist irredentism of the (E)thnic parties, it actively supported cultural and linguistic rights for Hungarians as part of its universalist and cosmopolitan message. With the exception of those areas where the Slovaks were a predominant majority, Hungarian support for the (C)ommunists falls as the local proportion of Hungarians increases.

\section{$5.2 \quad 1935$}

Let us turn now to the 1935 election results. Recall that in contrast with the 1929 election, which occurred in a context of relative amity among ethnic groups, the 1935 vote took place after the rise of Hitler and Stalin had emboldened extremist Czechoslovak political entrepreneurs. Czech Fascists now received over 7 percent of the vote. Konrad Henlein had assumed leadership of the German extreme Right and had established a Nazi Sudeten German party that won over 15 percent of the vote, becoming by far the largest German party. Hlinka's Slovak populists had begun to advocate an independent Slovak state rather than merely autonomy within Czechoslovakia. Our prediction is that the increased "ethnification" of politics at the national level should increase support for the threat hypothesis at the local level. Germans and Slovaks, previously merely dissatisfied citizens of the Republic, now could be seen by others as posing a threat to the Republic's very existence. This could very well drive fearful Czechs and Hungarians into the hands of their own extremists.

Figure 2 displays the social bases of bloc/party support in 1935, in a set of panels that is analogous to Figure 1. There are two key features of this figure. First, comparing Figures 1 and 2, the change in overall German electoral preferences is clearly visible in the Bohemia and Moravia panels, where the (N)azi Sudeten German Party, whose predecessor parties obtained at most one-third of the German vote, now grabs over 50 percent of that vote. This came at the expense of the more moderate $(\mathrm{G})$ erman parties, which still received a large portion of the vote, but not nearly as large as in 1929.

The increasing radicalization of the Slovak Protestants is not portrayed in the Slovak panel, but the numbers reveal their growing preference for Hlinka's 'autonomist' (P)opulists: their support for the (R)epublicans dropped from 94 percent to 73 percent $( \pm .1 \%)$, while their 'autonomist' Hlinka support increased from nil to 13 percent $( \pm 1 \%)$. Protestants still overwhelmingly favored liberal parties, but even their resistance was breaking. Slovak Catholic support for the (P)opulists and (R)epublicans remained remarkably steady at around 65 percent and 5 percent, respectively. The rise of fascism among Germans in Bohemia and Moravia and the continued popularity of the (P)opulist Slovak People's party in the Slovak heartland did not push Czechs into the arms of their own extremists. There was a slight uptick in support for Czech (F)ascist parties, but it was only 4-8 percent, and is barely visible on the panels. As the nominal ruling nationality the Czechs may have felt that the $(\mathrm{R})$ epublican parties were their best defense against threats to the republic. 
Bohemia, 1935

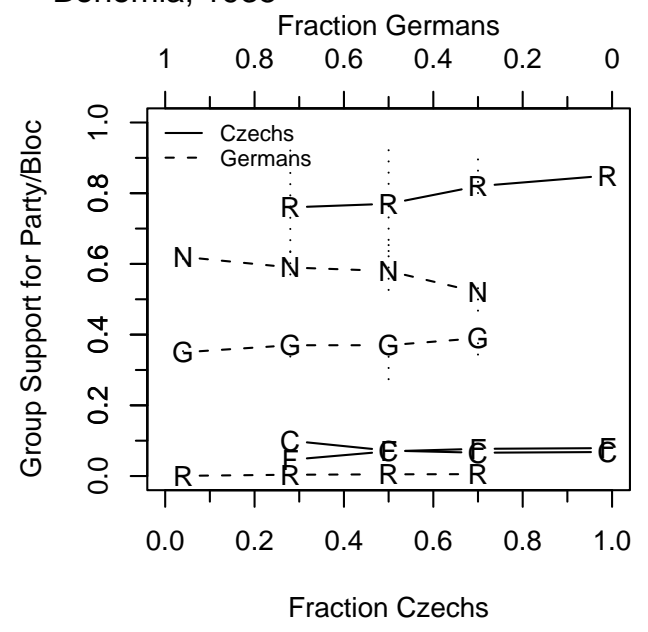

Slovakia, 1935

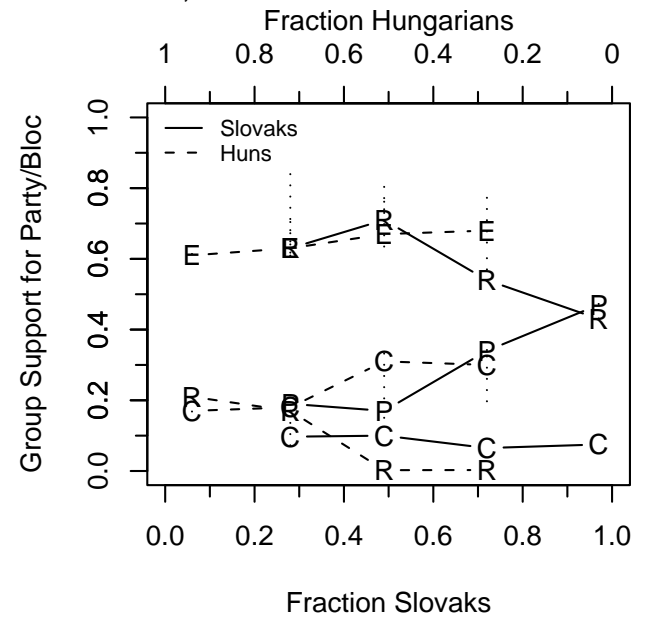

Moravia, 1935

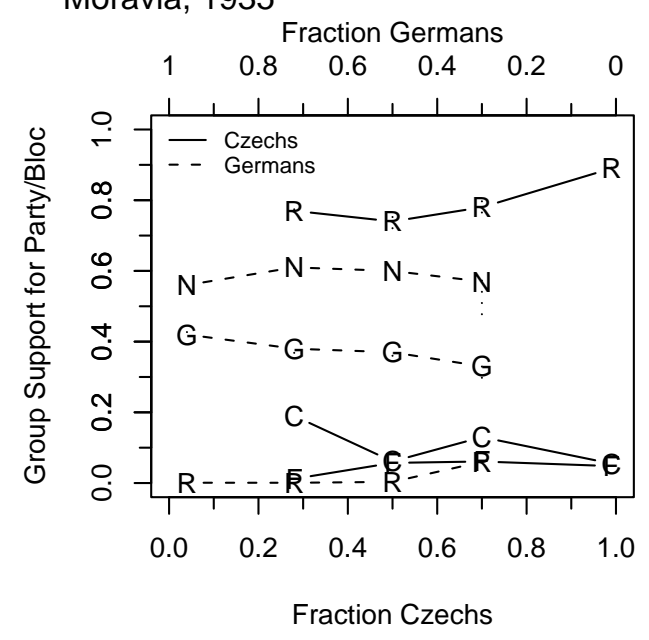

Key for Parties

$\mathrm{R}=$ Republican (Czechoslovak)

$\mathrm{C}=$ Communist

$\mathrm{N}=\mathrm{Nazi}$ (German)

$\mathrm{G}=$ German

$\mathrm{P}=$ Populists (Hlinka)

$\mathrm{F}=$ Nat Dems and Fascists

$\mathrm{E}=$ Ethnic min. non-German

Figure 2: Czechoslovakia 1935: Social Bases of Party Support

Second, our prediction regarding the consequences of increased ethnic tensions for local perception of threat is generally not borne out. There is a small but noticeable downward trend for the (N)azis in Bohemia and to a lesser extent Moravia, suggesting a weak version of the contact hypothesis: the more Germans were exposed to Czechs, the less likely they are to support the (N)azi party. However, the effect is slight. Thus, despite the change in fortunes of the German parties, at the local level German support remained more or less impervious to the presence of their Czech rivals. A similar argument can be made for the Hungarians. Their support for (E)thnic parties appears to be independent of whether they live among Slovaks or not, but a close comparison with Figure 1 reveals that this is due to a shift in only one data point, that for Hungarians in majority Slovak settlements. The only evidence for the threat hypothesis is their support for the (C)ommunists, which does increase a bit as they shift from local majority to local minority. The threat hypothesis still operates in Moravia for Czechs, whose support for (R)epublican parties peaks in 
purely Czech settlements, but the drop in support as they become a minority is not as steep as in 1929 .

\section{Discussion}

Thus far we have found mixed results for the relationship between local ethnic demography and mass electoral preferences. For Czechs and Hungarians our outcomes are consistent, on the whole, with the threat hypothesis: each group's support for liberal parties is at its maximum when it dwells as the local majority. Slovaks, by contrast, appear to benefit from contact: they are at their least liberal when they are in the local majority. German political behavior is largely immune to the presence of Czechs. These findings pose two further questions. First, how robust are the outcomes? Our results have been presented without conditioning on other factors because theory tells us that inter-ethnic contact should matter. However, class conflict also existed, and there is some overlap between class and ethnic cleavages. In the Czech lands the bourgeoisie was disproportionately Germans and in Slovakia it was disproportionately Jewish; Hungarians were overrepresented among large landowners; and Slovaks constituted the bulk of the peasantry. What appears as conflict between Hungarians and Slovaks or Czechs and Germans could actually have more to do with economic tensions than with ethnic competition per se. Second, assuming the results are robust, why should different groups respond to the presence of other groups in such starkly different ways? This question goes to the heart of how groups members perceive the threats emanating from members of other groups, and how that perception gets communicated at the electoral politics level. In this section we check the robustness of our earlier findings, and postpone discussion of the theoretical implications until the conclusion.

Is ethnicity a proxy for economic interest? We now condition some of the key findings on one socio-economic factor: employment in industry and manufacturing. We choose this because Czechoslovakia exhibited dramatic regional variation in its degree of industrialization. Significant parts of Bohemia and Moravia were as developed as any region in other industrialized countries, whereas other areas and much of Slovakia were mainly agricultural. Moreover, historians of East-Central Europe have shown that industrial employment closely tracks other socio-economic indictors such as literacy, consumption, and urbanization. ${ }^{10}$ Industrial employment is thus an excellent indicator for a congeries of factors besides ethnic contact that might influence the vote.

Unfortunately the economic data are available only at one administrative unit above the municipality, the judicial okres (or the political okres in the case of Slovakia). Although this yields over 300 units, there are insufficient data to reproduce all the estimates while fully controlling for relevant economic conditions. Instead, we focus on our two most prominent results: the rise in Czech preference for (R)epublican parties as they become the local majority in Moravia in 1929, and the decline in Slovak (R)epublican preferences as they become the local majority in 1935. We created sub-samples of municipalities based on whether the districts that

\footnotetext{
${ }^{10}$ See Berend and Ránki (1974).
} 
contain these settlements are above or below the median level of employment in industry and manufacturing. Across all districts in Moravia, approximately 40 percent of those employed worked in the industrial and manufacturing sectors. Slovakia was much less developed, with only 19 percent so employed. We then re-estimated key results in each sub-sample. In particular, we estimated Czech and Slovak support for those parties that interest us in areas where each group was a clear minority (between 10 and 40 percent of the population) and in those where they constituted a clear majority (greater than 80 percent of the local population). Our unconditioned results will be robust if there remains a similar gradient in preferences for liberal democratic parties within both the industrial and non-industrial sub-samples.

\subsection{Moravia, 1929}

Czech support for the major parties and blocs in Moravia are presented in Table 1, with the top two rows of estimates designating samples without the economic covariate (for reference), the next two designating the high manufacturing sample, and the last two the low-manufacturing sample. In each case 95 percent confidence intervals are listed in square brackets below each estimate. ${ }^{11}$ This table illustrates two key points. First, consistent with Figures 1 and 2, Czech support for (R)epublican parties (the first column of numbers) is much greater where Czechs are in a local majority, in both industrial and less industrial areas. The threat hypothesis appears robust. However, the situation is not so clear-cut if we also consider Czech vote for $(G)$ erman parties, which also accepted the rules of the democratic game. Without conditioning on industrialization (the top two rows of point estimates), Czechs still support liberal parties ( $(\mathrm{R})$ epublican or $(\mathrm{G})$ erman) in greater numbers where they live among themselves (92 percent) than when they live as a minority among Germans (83 percent), but this relationship is clearly being driven by high manufacturing areas, where the difference is 20 percentage points (89-69).

The substantial Czech preference for the parties of their ethnic rivals (29 percent in less industrial districts with majority German municipalities) is not as paradoxical as it may appear. These localities are concentrated in border districts such as Znojmo/Znaim, Moravske Krumlov/Märische Kromau, Mikulov/Nikolsburg and Dacice/Datschitz, on the Austrian border, where centuries of intermixing are likely to have made ethnic identities more fluid than they would be elsewhere (see King, 2002). The recent transfer of sovereignty from Austria-Hungary to Czechoslovakia undoubtedly induced some German-speakers to declare themselves "Czech" in the census, in deference to the new political order. Some evidence for this may be gleaned from the district of Mikulov/Nikolsburg. According to the 1910 Austro-Hungarian census, 46,907 Germans and only 1,251 Czechs dwelled there. By 1921, at the time of the first Czechoslovak census, there were 42,908 Germans and 6,353 Czechs. By

\footnotetext{
${ }^{11}$ In a few cases the point estimate from the full sample lies slightly outside the 95 percent confidence interval as computed from the posterior of the bootstrapped replications. The difference never has substantive significance, but we are exploring the potential role of influence points. We acknowledge these instances by extending the confidence interval to include the full sample estimate, and reporting that end of it in italics. In all cases we round off to the nearest integer. In many instances the intervals are so small that both endpoints of the interval are the same number.
} 


\section{Sample Type}

\section{Repub German Rep+Germ Comm}

$\begin{array}{lcccc}\begin{array}{l}\text { No Econ Controls } \\ \text { 10-40\% Czechs }\end{array} & 68 & 15 & 83 & 11 \\ & {[63,79]} & {[7,18]} & & {[8,11]} \\ & 92 & 0 & 92 & 6 \\ 80-100 \% & {[92,92]} & {[0,0]} & & {[6,6]} \\ & & & & \\ \text { High Manuf/Industry } & 69 & 0 & 69 & 19 \\ \text { 10-40\% Czechs } & {[69,75]} & {[0,0]} & & {[14,19]} \\ & 89 & 0 & 89 & 8 \\ \text { 80-100\% } & {[89,89]} & {[0,1]} & & {[8,8]} \\ & & & & \\ \text { Low Manuf/Industry } & 64 & 29 & 93 & 2 \\ \text { 10-40\% Czechs } & {[47,87]} & {[4,36]} & & {[2,2]} \\ & 95 & 0 & 95 & 5 \\ \text { 80-100\% } & {[95,95]} & {[0,0]} & & {[5,5]}\end{array}$

Table 1: Moravia 1929: Local Ethnic Balance and the Czech Vote in Industrial and Agricultural Districts. 95 percent confidence intervals are in brackets below each estimate.

1930 there were only 40,873 Germans and 9,055 Czechs. ${ }^{12}$ It seems unlikely that this dramatic "Czechification" is due solely to population movements arising from the war and founding of Czechoslovakia.

The second key point is that elevated support for the Communists in high manufacturing areas shows that local ethnic demography is not the whole story. It would be easy to explain away the communist vote as workers voting their interests, but the reality is more subtle. The Czechoslovak Social Democrats are one of the (R)epublican parties. They, too, appealed to the working class, and in the country as a whole received more votes than the Communists. If "interests" were the whole story, Czechs could just have well have voted Social Democratic. Party organization also mattered. Given the strength of the German parties, Czechoslovak parties tended to concentrate their resources in heavily Czech areas, where they were more likely to yield votes. The communists, however, were different. They sought out workers regardless of their national affiliation, but as elsewhere in Eastern Europe also played on ethnic divisions. They campaigned heavily in minority areas, and in fact were one of the few Czechoslovak parties with a significant organization

\footnotetext{
${ }^{12}$ See Bohmann (1959: 22).
} 
Sample Type

\section{Repub Ethnic Rep+Ethnic Comm Hlinka}

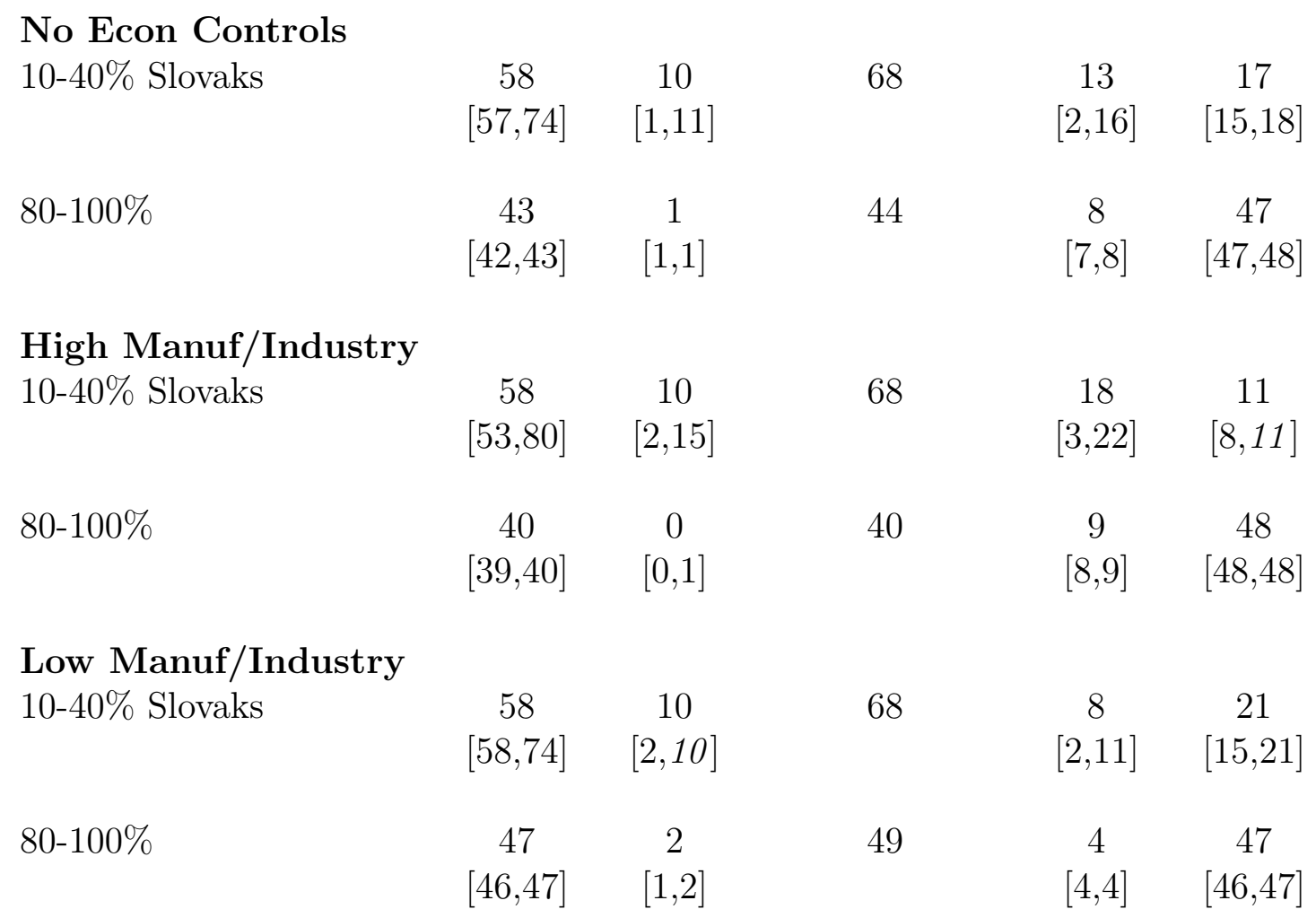

Table 2: Slovakia 1935: Local Ethnic Balance and the Slovak Vote in Industrial and Agricultural Districts. 95 percent confidence intervals are in brackets below each estimate.

within German regions (Jelinek 1983, pp.21-56, Rothschild 1974). However, electorally speaking they remained "Czechoslovak", receiving virtually no support from the Germans. For the Czechs in German dominated industrial regions, the Communists may well have served as both a protector of interests and as a Czechoslovak ethnic party that defended Czechs from perceived German, and especially bourgeois German exploitation.

\subsection{Slovakia, 1935}

We now turn to testing the robustness of the results in 1935 Slovakia. Our approach will be analogous to that followed for Moravia, with two caveats. First, Slovakia was far less industrialized than the Czech lands, so the median level of industrial employment across districts, the cutpoint at which we divide the subsamples, is 19 percent rather than 39 percent. Second, just as when we estimated the unconditioned effects, we were not able to factor in the effects both of confession and degree of contact. We will continue to use ethnic identity, it being understood that Slovak support for Hlinka represents disparate Catholic and Protestant behavior. As before, 
we exclude localities with significant numbers of Jews or Germans. Where Slovaks lived as a minority, they lived among Hungarians.

Table 2 presents these estimates, which umambiguously confirm the unconditioned effects from Figure 2. First, support for (R)epublican parties (the first column of numbers) remains higher in minority Slovak localities than in majority ones, regardless of whether they are located in industrial or non-industrial districts. Unlike for Moravia, however, this result remains even when preference for ethnic parties (in this case the Hungarian-German alliance) is taken into account. Contact with other minorities causes Slovaks to vote more liberal regardless of how one classifies the Hungarian-German alliance, and in both industrial and agricultural areas.

Second, similarly to Moravia, the nature of the Slovak response to the presence of their ethnic rivals depends on the socio-economic context in which contact occurs. To see this, consider Slovak voting behavior where they are in the minority (10$40 \%$ Slovaks). In industrialized regions they prefer the Communists (18 percent) to Hlinka (11 percent), whereas in less industrialized areas they much prefer Hlinka (21 percent) to the Communists ( 8 percent). The superior Communist performance in industrialized areas undoubtedly reflects greater organizational resources, but they still performed twice as well in minority Slovak communities (18 percent) than in majority Slovak ones (9 percent). This suggests that the Communists may also have succeeded in capitalizing on the threat Slovaks perceived from their more numerous Hungarian neighbors.

\section{Conclusion}

Does familiarity breed contempt? Our primary conclusion is that in and of itself, the political consequences of contact are indeterminate. First, there is not a uniform pattern across ethnic groups. By and large for Czechs and to a lesser extent Hungarians contact with other groups has deleterious effects. For Slovaks propinquity with Hungarians is associated with greater tolerance, while Germans seem impervious to the presence of their Czech neighbors. Second, the impact of ethnic demography is not consistent within ethnic groups. For Czechs the perceived German threat is primarily an industrial phenomenon, whereas for Slovaks the industrial environment does not significantly alter the benefits of contact. The ethnically charged atmosphere of 1935 slightly diminishes the earlier negative consequences of contact for Czechs and Hungarians, but largely preserves the positive effects for Slovaks and neutral ones for Germans.

These contradictory findings are discordant with the literature, the vast majority of which finds contact to have positive effects. Pettigrew and Tropp (2006: 767) note that a key limitation of contact research has been its single-minded focus on circumstances that facilitate beneficial contact. They suggest that scholars ought instead to devote greater energy to inhibitory factors. Taken together, our disparate results shed light on at least two potential determinants. The first is national demography. One might have expected similarities between German and Hungarian political behavior. Both were former ruling nationalities who were unwilling and unhappy minorities in Czechoslovakia. Yet the Germans proved far more immune 
to contact than the Hungarians. The difference may lie in their numbers. Germans constituted roughly one-quarter of the Czechoslovak population and nearly one-third of Bohemia, a demographic weight that supported a broad range of political parties and economic influence that may have reduced fears of Czech political domination. This could explain their political disregard for the presence of Czechs. The Hungarians, by contrast, constituted less than 5 percent of Czechoslovakia and only around 17 percent of Slovakia, making the Slovaks are far greater potential threat to them than the Czechs were to the Germans.

The second factor is national-level ethnic politics, which does not appear to exert much influence. This is a remarkable finding given the volume of ink spilled on the dangers of ethnic outbidding and the importance of amicable peak-level ethnic relations. As noted earlier, by 1935 Germany and Hungary were agitating ever more openly for territorial revision, and each, along with the Soviet Union, was supporting "their" parties within the Czechoslovak party system. Even the most isolated of Czechoslovak citizens could not have entered the voting booth in 1935 unaware of the steady deterioration in inter-ethnic relations and the threat posed to the republic. Yet none of this fundamentally altered the logic of contact as it existed in 1929, even if it did slightly reduce the magnitude of some effects. German support did shift en masse to Henlein's Sudeten Nazi party, but even those gains occurred more or less equally in homogeneously German and mixed German-Czech settlements. Our results breathe new life into the old adage that all politics is local.

A third implication of our findings concerns the relationship between the degree of contact and the nature of the hypothesized outcome. Close inspection of Figures 1 and 2 reveals potential non-monotonic effects, with an inflection point occurring in roughly evenly-balanced settlements (40-60 percent Czech/Slovak). Such behavior appears to characterize German support for $(\mathrm{G})$ erman and (N)azi parties, Hungarian support for the (C)ommunists, and Slovak support for (R)epublican parties in 1929; and Czech support for the (C)ommunists and Slovak support for (R)epublicans and (P)opulists in 1935. This pattern is based on relatively few data points, and requires further investigation, but there are good theoretical reasons for believing that evenly-divided localities might be different. For example, uncertainty about which kind of party will emerge politically victorious, and the likelihood that authority is likely to shift again in the future, might encourage all groups to support more liberal parties. This is in contrast to areas in which a group is a small minority or overwhelmingly majority. In the former case extremist voting poses little threat to the ruling majority group, whereas in the latter the majority can vote extremist without fear of retaliation by the minority. This logic may be more pertinent to local than national elections, but nonetheless both Germans and Slovaks (though not Czechs) are at their most liberal in evenly-balanced settlements.

We conclude by mentioning one small contribution to our understanding of interwar Czechoslovakia. War and communism have meant that the political sociology of this period remains largely terra incognita. Hitherto, the electoral preferences of Czechoslovakia's various ethnic groups has been inferred from the voting results of ethnically homogeneous settlements. In essence, the literature has focused mainly on those areas on the far left and right of the panels in Figures 1 and 2. Given the tendency of the larger ethnic groups to dwell in their own communities, this might 
provide a reasonably accurate national picture of group electoral behavior. However, as our analysis as shown, such an approach gives short shrift to the often dramatic but certainly unexpected electoral consequences of intergroup contact. On its own familiarity breeds neither amity nor contempt. 


\section{Appendix}

\section{Czechoslovakia Party Blocs}

Communist 1929: List 1-Communists

Republican 1929: List8-Narodne-socialisticke, List 10-Socialne-demokraticke strany delnicke, List 13-Narodni Demokracie, List 14-Lidove, List 15-Republikanske strany zemedelskeho a malorolnickeho lidu, List 16-Zivnostensko-obchodnickestrany stredostavovske

German 1929: List 3-Nemeckeho volebniho spolecenstvi, List 4-Nemecke socialnedemokraticke strany delnicke, List 17-Nemecke krest'ansko-socialni strany lidove a nemecke strany zivnostenske

German Nazi 1929: List 6-Nemecke narodni strany a sudetsko-nemeckeho zemedelskeho svazu, List19-Nemecke narodne-socialisticke strany delnicke

Other ethnic 1929: List 2-Zemske krest'ansko-socialni, madarske narodni a spisskonemecke strany, List 5-Volebniho sdruzeni polskych stran a zidovskych stran

Hlinka 1929: List 18-Hlinklovy slovenske ludove strany

Communist 1935: List 4-Communists,

Republican 1935: List 1-Republicans, List 2-Czechoslovak social democracy, List 3-Czech national socialists, List 5-Czech people's party (Sramek), List 10-Cs Zivn obch

German 1935: List 6-German social democrats, List 8-Bund der Landeswirte, List 9-German Christian Socialists

Czechoslovak fascists 1935: Narodni obec fasist

Hlinka 1935: List 7-Aut. blok (Hlinka)

Henlein 1935: List 12-SDP

Hungarian 1935: Kraj krest' soc. mad' n. a Wahlblock 


\section{Bibliography}

Allport, Gordon. 1954. The Nature of Prejudice. Cambridge: Cambridge University Press.

Berend, Iván T. and György Ránki. 1974. Economic Development in East-Central Europe in the 19th and 20th Centuries. New York: Columbia University Press.

Blalock, Hubert M. 1967. Toward a Theory of Minority Group Relations. New York: Wiley.

Blumer, Herbert. 1958. "Race Prejudice as a Sense of Group Position." Pacific Sociological Review 1(1): 3-7.

Bobo Lawrence, and Vincent Hutchings. 1996. "Perceptions of Racial Group Competition: Extending Blumer's Theory of Group Position to a Multiracial Social Context." American Sociological Review 61 (6): 951-72.

Bohmann, Alfred. 1959. Das Sudetendeutschtum in Zahlen. München: Sudetendeutscher Rat.

Brewer, Marilyn, and Norman Miller. 1988. "Contact and Cooperation: When Do They Work?" In Eliminating Racism, ed. Phyllis Katz and Dalmas Taylor, New York: Plenum Press.

Brubaker, Rogers. 1993. Nationalism Reframed. Cambridge: Cambridge University Press.

Dahl, Robert. 1971. Polyarchy: Participation and Opposition. New Haven: Yale University Press.

Felak, James. 1994. At the Price of the Republic: Hlinka's Slovak People's Party 1929-1938. Pittsburgh: University of Pittsburgh Press.

Giles W. Michael and Melanie A. Bruckner. 1993. "David Duke and the Black Threat: An Old Hypothesis Revisited." Journal of Politics. 55(3):702-713.

Glazer, James M. 2003. "Social Context and Inter-Group Political Attitudes: Experiments in Group Conflict Theory." British Journal of Political Science. 33 (3):607-620.

Hoensch, Joerg. 1978. Geschichte der Tsechoslowakische Republik. 1918-1978. Stuttgart: Verlag Kolhammer.

Hoensch, Joerg. 1979. Die Slowakische Volkspartei Hlinkas. In Bosl, Die Erste Tschechoslowakische Republik als Multinationaler Parteienstaat. Vienna: Oldenbourg Verlag.

Horowitz, Donald. 1985. Ethnic Groups in Conflict. Berkeley: University of California Press.

Janos, Andrew. 1982. The Politics of Backwardness in Hungary, 1925-1945. Princeton, NJ: Princeton University Press.

Jelinek, Yeshayahu. 1983. The Lust for Power: Nationalism, Slovakia, and the Communists, 1918-1948. Boulder CO: East European Monographs.

King, Jeremy. 2002. Budweisers into Czechs and Germans. Princeton NJ: Princeton University Press.

Kirschbaum, Stanislav. 2005. A History of Slovakia: the Struggle for Survival. London: Palgrave. 
Leff, Carol S. 1988. National Conflict in Czechoslovakia: The Making and Remaking of a State 1918-1987. Princeton: Princeton University Press

Lijphart, Arend. 1977. Democracy in Plural Societies. New Haven: Yale University Press.

Lipscher, Ladislav. 1981. "Die Parteipolitische Struktur der Minderheiten und Ihre Staatsrechtlichen Vorstellungen zu Lösung der Nationalen Frage in der Tschechoslowakei (1918-1930). Bohemia, 22: 342-380.

Mamatey, Victor S. and Radomír Luža. 1973. A History of the Czechoslovak Republic. Princeton: Princeton University Press.

McDermott, Kevin. 1988. The Czech Red Unions, 1918-1929. Boulder CO: East European Monographs.

Oschlies, Wolf. 1979 "Die Kommunistische Partei der Tschechoslowakei als politische Organisation 1920-1938," in Bosl, Karl. Die Erste Tschechoslowakische Republik als Multinationaler Parteienstaat. Vienna: Oldenbourg Verlag.

Oliver, Eric J. and Janelle Wong. 2003. "Intergroup Prejudice in Multiethnic Settings." American Journal of Political Science. 47(4):567-582.

Pettigrew, Thomas F. and Linda R. Tropp. 2006. "A Meta-Analytic Test of Intergroup Contact Theory," Journal of Personality and Social Psychology, Vol. 90, No. 5, 751-783.

Polonsky, Antony. 1972. Politics in Independent Poland, 1921-1939. Oxford: Oxford University Press.

R Development Core Team (2005). R: A language and environment for statistical computing. R Foundation for Statistical Computing, Vienna, Austria. ISBN 3-900051-07-0, URL http://www.R-project.org.

Rosen, Ori, Wenxin Jiang, Gary King, and Martin A. Tanner, "Bayesian and frequentist inference for ecological inference: the RxC case," Statistca Neerlandica, Vol. 55, nr. 2, pp. 134-156.

Rothschild, Joseph. 1974. East Central Europe Between the Two World Wars. Seattle: University of Washington Press.

Seton-Watson, R. W. 1908 Racial Problems in Hungary. The Southern Slav Question in the Hapsburg Monarchy. London.

Siegelman, Lee, and Susan Welch. 1993. "The Contact Hypothesis Revisted: Black White Interaction and Positive Social Attitudes. Social Forces. 71(3):781-95.

Siegelman Lee, Timothy Bledsoe, and Michael Combs. 1996. "Making Contact? Black, White Social Interaction in an Urban Setting." American Journal of Sociology. 101(5):1306-32.

Stein, Robert, Stephanie Post , Allison Rinden. 2000. "Reconciling Context and Contact Effects on Racial Attitudes." Political Research Quarterly, 53: 285-303.

Voss, Stephen D. 1996. "Beyond Racial Threat: Failure of an Old Hypothesis in the New South." Journal of Politics. 58(4):1156-1170.

Welch Susan and Lee Siegelman. 2000. "Getting to Know You? Latino-Anglo Contact." Social Science Quarterly. 81(1):67-83.

Wingfield, Nancy. 1989. Minority Politics in a Multinational State : the German Social Democrats in Czechoslovakia, 1918-1938. Boulder CO: East European 
Monographs.

Wiskemann, Elizabeth. 1967 (1938). Czechs and Germans. London: Macmillian.

Wittenberg, Jason and Badri Narayan Bhaskar, "R Code for RxC Ecological Inference." Version December 1, 2005, University of California, Berkeley.

Wright, Gerald. 1977. "Contextual Models of Electoral Behavior: The Southern Wallace Vote." American Political Science Review 71(2):497-508. 